\title{
BIOMASS FUEL USERS WOMEN AND CHRONIC OBSTRUCTIVE PULMONARY DISEASES IN WOMEN IN RURAL AREA M. KHOTWADI OF SANGLI DISTRICT.
}

\author{
P.M. Patil \\ Department of Zoology, Dr. Patangrao Kadam Mahavidyalaya, Sangli \\ E mail: patilpm16@gmail.com
}

\begin{abstract}
:
On a global scale the household use of solid fuels is the most important source of indoor pollution and the exposure to the byproducts of combustion of biomass fuel particularly wood smoke has been related to chronic obstructive pulmonary diseases. In India 95\% households use wood as the primary cooking fuel. The smoke released due to incomplete combustion of unprocessed solid biomass fuel contains high volume and number of health damaging air borne pollutants such as $\mathrm{PM}, \mathrm{CO}, \mathrm{NO} 2, \mathrm{SO} 2$ formaldehyde and other organic compound. Prolong exposure to such air borne pollutants have adverse effect on lung function which causes COPD in which lung functions is reduced. In this study 50 women exposed to biomass fuel were selected form village M.Khotwadi. Information regarding age, height, weight, type of fuel, number of hrs exposed to smoke, no. of yrs., types of kitchen were collected.Spirometry was performed in these women. Spirometric parameter forced expiratory volume per second and forced viral capacity were recorded. In this study we found out of 50 women $24(48 \%)$ were suffered from COPD.
\end{abstract}

Keywords: COPD, Biomass Fuel, FEV1 (Forced Expiratory Volume per one second), FVC (Forced Vital Capacity)

\section{INTRODUCTION:}

On a global scale the household use of solid fuels is the most important source of indoor pollution and the exposure to the byproducts of combustion of biomass fuel particularly wood smoke has been related to chronic obstructive pulmonary diseases. Half of the world population and $75 \%$ population of developing countries still depends upon biomass fuel as a primary source of domestic energy for cooking and heating. (Reddy, et al 1990; Desai, et al 2004, Smith, et al.; 2004). Biomass fuel such as wood, plant residues and cow dung especially used for cooking and heating purpose (Nigel Bruce, et al 1988) biomass accounts for more than $80 \%$ of domestic energy in India (Holdren et al ;2000).In India 90\% household's use wood or animal dung as the primary cooking fuel (IIps). The most important factor in the life of average Indian housewife is the domestic cooking. The typical Indian household life revolves around the cooking area and Indian women spent much of the time there. For daily cooking Indian housewife spent on an average more than 6 hours in the kitchen for cooking food (morning and evening). During her lifetime she is exposed to biomass fuel for 30 to $40 \mathrm{yrs}$. The type of house, location of kitchen and type of fuel used play a significant role on women health.
The smoke released due to incomplete combustion of unprocessed solid biomass fuel contains high volume and number of health damaging air borne pollutants such as (PM) respirable particulate matter $\mathrm{PM} 10, \mathrm{CO}, \mathrm{NO} 2$, $\mathrm{SO} 2$, formaldehyde and other organic compounds (Bruce et al., 2000) Prolong exposure to such air born pollutants have adverse effect on the respiratory system of women which causes COPD.COPD is the inflammation and swelling of the lining of the airways that leads to narrowing and obstruction of the airways. In rural areas, most common cause of COPD is air pollution.

\section{MATERIAL \& METHODS:}

Total 100 women were participated in this study. The biomass fuel users group was represented by 50 women from M.Khotwadi. Another group of LPG users was represented by 50 women from same villages of Sangli district. All women were 25 years of age or older. Biomass fuel users were from low socioeconomic status. All women were interviewed and information was collected about age, height, weight type of house, type of Kitchen, no. of years exposure to biomass smoke, no. of hrs/day exposed to smoke. Spirometrywas performed in 100women, 50 biomass fuel users (subjects) and 50 LPG users (control). Force expiratory volume/ 1 second (FEV1\%) and ratio 
of force expiratory volume/1second / force vital capacity were recorded. Women having FEV1\% $<70 \%$ were considered as COPD.

\section{Statistical analysis:}

$Z$ significance test was used. ' $Z$ ' value for control and subject was calculated, using formula based on null hypothesis to show significant difference between control and subject.

$$
\operatorname{Cal}|z|=\left[\frac{\overline{x 1}-\overline{x 2}}{\sqrt{\frac{\sigma 1^{2}}{n_{1}}+\frac{\sigma 2^{2}}{n_{2}}}}\right]
$$

$\overline{x 1}$ Mean of subject

\section{$\overline{x 2}$}

Mean of Control

$\overline{\sigma 1}$ Standard devaation of subject $\quad \overline{\sigma 2}$

Standard devaation of subject

$\mathrm{n} 1=$ Number of observations of subjects

$\mathrm{n} 2=$ Number of observations of control

HO: There is no significant difference between control and subject women FEV1.

$\mathrm{V} / \mathrm{s}$

$\mathrm{H} 1$ : There is significant difference between control and subject women FEV1.

Cal $|Z|=>$ table $Z=1.96$ at $5 \%$ level of significance.

$\therefore$ Reject $\mathrm{HO}$

$\therefore$ There is significance difference between control and subject.

\section{RESULT AND DISCUSSION}

Table No.1 represents observations on Age, years of exposure and spirometry (in percentage) of control and Subject women in the village M. Khotwadi. The mean values of Age and years of exposure of control women are 42.20 and 20.20. While mean values of Age and year of exposure of subject women are 43.58 and 22.34. The mean values of $\mathrm{FEV}_{1} \%, \mathrm{FVC} \%$, $\mathrm{FEV}_{1} / \mathrm{FVC} \%$, of control women are 99.18, 91.77 and 85.31 respectively, the mean values of $\mathrm{FEV}_{1} \%, \mathrm{FVC} \%, \mathrm{FEV}_{1} / \mathrm{FVC} \%$ of Subject women are $73.46,76.67$ and 79.00 respectively. These values are shown at the base of each column in the Table No.1.

The calculated $Z$ value of Age and years of exposure and calculated $Z$ value of $\mathrm{FEV}_{1} \%$, $\mathrm{FVC} \%, \mathrm{FEV}_{1} / \mathrm{FVC} \%$ based on null hypothesis are at the last of each column in the Table No.1. The calculated $Z$ value of Age and years of exposure are 1.77 and 0.13 . The calculated $Z$ values of Age and years of exposure are less than 1.96 hence there is no significant difference in age and year of exposure of control and subject women. While calculated $Z$ values of $\mathrm{FEV}_{1} \%, \mathrm{FVC} \%$ and $\mathrm{FEV}_{1} / \mathrm{FVC} \%$ are 6.12, 3.98 and 4.41 respectively. The calculated $\mathrm{Z}$ values of $\mathrm{FEV}_{1} \%, \quad \mathrm{FVC} \%, \quad \mathrm{FEV}_{1} / \mathrm{FVC}^{2} \%$ are greater than 1.96 hence there is significant difference in $\mathrm{FEV}_{1} \%, \mathrm{FVC} \%, \mathrm{FEV}_{1} / \mathrm{FVC} \%$ of control and subject women. The result is significant at $5 \%$ level of significance.

In this study we found that out of 50 women using chulla from rural area M. Khoutwadi 24 women were having FEV1\% < 70. In $\mathrm{M}$. Khotwadi 24 women were suffered from obstructive type of disorder. Our results are similar with the results of Dennis et al. (1996), Orozco et al. (2006), Caballero et al. (2008). In obstructive type of spirometry pattern there is narrowing of small airways due to chronic inflammation. According to Dennis et al. (1996), Orozco et al. (2006), Caballero et al. (2008) the reduction in $\mathrm{FEV} 1 \%$ \& $\mathrm{FEV} 1 / \mathrm{FVC} \%$ may be due to chronic inhalation of toxic substances emitted during biomass combustion leading to inflammatory changes in (bronchi and bronchioles).

\section{REFERENCES :}

Caballero, A., Torres-Duque, C.A., Jaramillo, C., Bolivar, F., Sanabria, F., Osorio, P., Orduz, C., Guevara, D.P., Maldonado, D. (2008): Prevalence of COPD in five Colombian cities situated at low, medium, and high altitude (PREPOCOL study). Chest. 133(2):343-349.

Dennis, R.J., Maldonado, D., Norman, S., Baena, E., \& Martinez, G. (1996): Woodsmoke exposure and risk for obstructive airways disease among women. Chest. 109(1):115-9.

Desai, M.; Mehta S.; Smith, K. (2004) : Indoor smoke from solid fuels assessing the environmental burden of disease at national and local levels. Geneva, Switzerland, World Health organization. 
Holdren, J.P. and Smith, K.R. (2000) : Energy, The environment, and health. In J Goldemberg (Ed.)., The Word Energy Assessment: Energy and the Challenge of Sustainability (pp.61-110)., New York: United National Development Programme.

IIPS - International Institute for Population Science. National family health survey (MCH and family planning); India 1992-93, International Institute for Population Science, Bombay 1995.

Liu, S.; Zhou, Y.; Wang, X.; Wang, D.; Lu, J.; Zheng, N.; Ran, P. (2007): Biomass fuels are the probable risk factor for chronic obstructive pulmonary disease in rural south china., Thorax., 62 : 889-897.

Malik S K. Respiratory effects of effects of domestic cooking with particular reference to kerosene oil and liquefied petroleum gas. Bull PGI 1984; 18: 4 .

Nigel Bruce, Lynnette Neufeld, Erick Boy, and chris west (1998): Indoor biofuel air pollution and respiratory health the role of confounding factors among women in highland Guatemala., International Journal ofEpidemiology, Volume 27, 454458.

Orozco-Levi, M., Garcia, Aymerich, J., Villar, J., Ramirezsarmiento, A., Anto, J.M. and Gea, J. (2006): Wood smoke exposure and risk of chronic obstructive pulmonary disease. European Respiratory Journal. 27:542-546.

Pandey MR. Domestic smoke pollution and chronic bronchitis in a rural community of the Hill region of Nepal. Thorax 1984; 39:337-39.

Table No. - 1

Data of Spirometry (FEV $\%$, FVC\%, FEV 1 FVC\%) of Rural Women from M. Khotwadi Exposed to Biomass smoke

\begin{tabular}{|c|c|c|c|c|c|c|c|c|c|c|}
\hline \multirow{2}{*}{$\begin{array}{l}\text { Sr. } \\
\text { No. }\end{array}$} & \multicolumn{5}{|c|}{ CONTROL } & \multicolumn{5}{|c|}{ SUBJECT } \\
\hline & Age & $\begin{array}{l}\text { Year } \\
\text { s }\end{array}$ & FEV $_{1} \%$ & FVC\% & $\begin{array}{l}\text { FEV } 1 / \\
\text { FVC\% }\end{array}$ & Age & $\begin{array}{l}\text { Year } \\
\text { s }\end{array}$ & $\operatorname{FEV}_{1} \%$ & FVC\% & $\begin{array}{l}\text { FEV } 1 / \\
\text { FVC\% }^{2}\end{array}$ \\
\hline 1 & 39 & 12 & 79.00 & 77.73 & 79.53 & 42 & 23 & 76.23 & 71.92 & 90.91 \\
\hline 2 & 40 & 23 & 92.79 & 91.43 & 86.16 & 38 & 18 & 99.12 & 89.06 & 95.76 \\
\hline 3 & 41 & 25 & 101.27 & 96.37 & 86.02 & 36 & 17 & 93.80 & 98.73 & 82.64 \\
\hline 4 & 42 & 24 & 87.58 & 86.26 & 88.47 & 38 & 14 & 95.07 & 91.43 & 86.16 \\
\hline 5 & 37 & 20 & 121.33 & 114.67 & 86.26 & 40 & 19 & 68.98 & 80.66 & 75.44 \\
\hline 6 & 52 & 13 & 121.33 & 114.67 & 86.26 & 45 & 25 & 21.56 & 25.74 & 69.23 \\
\hline 7 & 46 & 28 & 83.04 & 77.73 & 83.04 & 48 & 29 & 61.43 & 76.77 & 66.15 \\
\hline 8 & 38 & 21 & 79.00 & 77.73 & 78.95 & 44 & 24 & 21.56 & 25.74 & 69.23 \\
\hline 9 & 45 & 27 & 121.33 & 114.67 & 86.26 & 45 & 24 & 54.46 & 67.47 & 69.05 \\
\hline 10 & 40 & 11 & 101.27 & 96.37 & 86.02 & 42 & 21 & 45.62 & 58.04 & 67.93 \\
\hline 11 & 38 & 21 & 121.33 & 114.67 & 86.26 & 45 & 13 & 98.03 & 91.30 & 88.69 \\
\hline 12 & 45 & 26 & 121.33 & 114.67 & 86.26 & 43 & 23 & 76.23 & 71.92 & 90.91 \\
\hline
\end{tabular}




\begin{tabular}{|c|c|c|c|c|c|c|c|c|c|c|}
\hline \multirow{2}{*}{$\begin{array}{l}\text { Sr. } \\
\text { No. }\end{array}$} & \multicolumn{5}{|c|}{ CONTROL } & \multicolumn{5}{|c|}{ SUBJECT } \\
\hline & Age & $\begin{array}{l}\text { Year } \\
\text { s }\end{array}$ & FEV $_{1} \%$ & FVC\% & $\begin{array}{l}\text { FEV }_{1 /} \\
\text { FVC\% }\end{array}$ & Age & $\begin{array}{l}\text { Year } \\
\text { s }\end{array}$ & FEV $_{1} \%$ & FVC\% & $\begin{array}{l}\text { FEV }_{1 /} \\
\text { FVC\% }\end{array}$ \\
\hline 13 & 46 & 29 & 98.03 & 91.30 & 88.69 & 46 & 29 & 58.28 & 63.45 & 76.00 \\
\hline 14 & 37 & 12 & 83.04 & 77.73 & 83.04 & 40 & 20 & 50.00 & 58.15 & 70.09 \\
\hline 15 & 40 & 22 & 105.18 & 102.62 & 86.38 & 46 & 22 & 87.33 & 89.67 & 79.39 \\
\hline 16 & 42 & 24 & 83.04 & 61.07 & 83.04 & 41 & 14 & 40.96 & 53.36 & 64.71 \\
\hline 17 & 48 & 30 & 87.33 & 75.00 & 79.39 & 48 & 25 & 121.33 & 114.67 & 86.26 \\
\hline 18 & 39 & 22 & 87.33 & 58.51 & 79.39 & 49 & 27 & 54.46 & 67.47 & 69.05 \\
\hline 19 & 40 & 13 & 121.33 & 114.67 & 86.26 & 43 & 22 & 101.27 & 96.37 & 86.02 \\
\hline 20 & 48 & 30 & 80.67 & 58.51 & 73.33 & 48 & 29 & 45.62 & 58.04 & 67.93 \\
\hline 21 & 39 & 21 & 98.03 & 91.30 & 88.69 & 38 & 28 & 40.96 & 53.36 & 64.71 \\
\hline 22 & 49 & 33 & 121.33 & 114.67 & 86.26 & 49 & 25 & 96.02 & 91.43 & 86.16 \\
\hline 23 & 49 & 30 & 101.27 & 96.37 & 86.02 & 49 & 29 & 53.37 & 36.36 & 80.56 \\
\hline 24 & 45 & 28 & 101.27 & 96.37 & 86.02 & 46 & 27 & 48.55 & 75.21 & 73.63 \\
\hline 25 & 40 & 13 & 101.27 & 96.37 & 86.02 & 36 & 18 & 71.19 & 72.70 & 84.39 \\
\hline 26 & 37 & 20 & 87.58 & 86.26 & 88.47 & 46 & 14 & 109.82 & 98.48 & 92.27 \\
\hline 27 & 39 & 21 & 98.03 & 91.30 & 88.69 & 39 & 21 & 68.80 & 73.90 & 80.10 \\
\hline 28 & 40 & 22 & 87.58 & 86.26 & 88.47 & 45 & 24 & 83.51 & 77.58 & 90.75 \\
\hline 29 & 43 & 12 & 101.27 & 96.37 & 86.02 & 47 & 28 & 74.64 & 76.61 & 78.63 \\
\hline 30 & 42 & 23 & 87.33 & 58.51 & 79.39 & 46 & 27 & 57.08 & 61.99 & 79.17 \\
\hline 31 & 44 & 27 & 83.04 & 77.73 & 83.04 & 42 & 22 & 66.29 & 83.33 & 66.29 \\
\hline 32 & 41 & 24 & 98.03 & 91.30 & 88.69 & 49 & 13 & 81.44 & 78.88 & 89.96 \\
\hline 33 & 39 & 11 & 87.58 & 86.26 & 88.47 & 42 & 22 & 61.43 & 77.69 & 66.15 \\
\hline 34 & 43 & 23 & 98.03 & 91.30 & 88.69 & 43 & 20 & 87.33 & 89.67 & 79.39 \\
\hline 35 & 38 & 20 & 121.33 & 114.67 & 86.26 & 45 & 25 & 70.94 & 65.56 & 91.14 \\
\hline 36 & 46 & 29 & 98.03 & 91.30 & 88.69 & 49 & 28 & 67.58 & 66.82 & 83.67 \\
\hline 37 & 38 & 12 & 101.27 & 96.37 & 86.02 & 42 & 20 & 73.79 & 80.49 & 76.77 \\
\hline 38 & 39 & 21 & 121.33 & 114.67 & 86.26 & 55 & 35 & 61.43 & 77.69 & 66.15 \\
\hline 39 & 41 & 24 & 121.33 & 114.67 & 86.26 & 49 & 29 & 76.23 & 71.20 & 91.82 \\
\hline 40 & 49 & 30 & 83.04 & 61.07 & 83.04 & 46 & 25 & 66.29 & 97.22 & 66.29 \\
\hline 41 & 44 & 27 & 83.04 & 61.07 & 83.04 & 43 & 20 & 87.33 & 89.67 & 79.39 \\
\hline 42 & 43 & 26 & 121.33 & 114.67 & 86.26 & 39 & 17 & 73.79 & 80.49 & 76.77 \\
\hline 43 & 40 & 22 & 101.27 & 96.37 & 86.02 & 43 & 20 & 166.27 & 142.11 & 85.19 \\
\hline 44 & 37 & 10 & 101.27 & 96.37 & 86.02 & 44 & 21 & 121.33 & 114.67 & 86.26 \\
\hline 45 & 45 & 26 & 98.03 & 91.30 & 88.69 & 42 & 22 & 61.43 & 77.69 & 66.15 \\
\hline 46 & 47 & 28 & 121.33 & 114.67 & 86.26 & 41 & 19 & 109.82 & 98.48 & 92.27 \\
\hline 47 & 42 & 24 & 87.58 & 86.26 & 88.47 & 38 & 18 & 77.08 & 83.33 & 77.89 \\
\hline 48 & 44 & 23 & 83.04 & 77.73 & 83.04 & 37 & 20 & 70.94 & 65.56 & 91.14 \\
\hline 49 & 40 & 22 & 105.18 & 102.62 & 86.38 & 39 & 19 & 76.23 & 71.92 & 90.91 \\
\hline
\end{tabular}




\begin{tabular}{|c|c|c|c|c|c|c|c|c|c|c|}
\hline \multirow{2}{*}{$\begin{array}{l}\text { Sr. } \\
\text { No. }\end{array}$} & \multicolumn{5}{|c|}{ CONTROL } & \multicolumn{5}{|c|}{ SUBJECT } \\
\hline & Age & $\begin{array}{l}\text { Year } \\
\text { s }\end{array}$ & FEV $_{1} \%$ & FVC\% & $\begin{array}{l}\text { FEV }_{1 /} \\
\text { FVC\% }\end{array}$ & Age & $\begin{array}{l}\text { Year } \\
\text { s }\end{array}$ & $\operatorname{FEV}_{1} \%$ & FVC\% & $\begin{array}{l}\text { FEV }_{1} / \\
\text { FVC }^{\prime}\end{array}$ \\
\hline 50 & 44 & 25 & 82.56 & 77.73 & 83.04 & 43 & 23 & 40.96 & 53.36 & 64.71 \\
\hline Mean & $\begin{array}{l}42.2 \\
0\end{array}$ & $\begin{array}{l}22.2 \\
0\end{array}$ & 99.18 & 91.77 & 85.31 & $\begin{array}{l}43.5 \\
8\end{array}$ & $\begin{array}{l}22.3 \\
4\end{array}$ & 73.46 & 76.67 & 79.00 \\
\hline Var. & $\begin{array}{l}13.9 \\
6\end{array}$ & $\begin{array}{l}35.8 \\
4\end{array}$ & 208.02 & 293.64 & 10.24 & $\begin{array}{l}16.4 \\
8\end{array}$ & $\begin{array}{l}23.1 \\
4\end{array}$ & 674.61 & $\begin{array}{l}427.5 \\
3\end{array}$ & 92.09 \\
\hline Sqrt & 0.78 & 1.09 & 4.20 & 3.80 & 1.43 & & & & & \\
\hline $\mathbf{Z}$ & 1.77 & 0.13 & 6.12 & 3.98 & 4.41 & & & & & \\
\hline
\end{tabular}

